\title{
Security and the Dearth of Live Theatre in Nigeria
}

\section{Toyin Ogundeji}

Department of Dramatic Arts, ObafemiAwolowo University, Ile-Ife, toluye2000@yahoo.co, olujuwa@oauife.edu.ng

\section{Doi:10.5901/mjss.2016.v7n2s1p238}

\section{Abstract}

There has been a great acceptance of live performances in the history of Nigerian theatre as evident in the shows of itinerant and literary theatres between 1960s and 1980s, for many people were enamoured of the productions of the Yoruba travelling theatre troupes and literary drama as produced by some Universities with theatre arts departments, such as the University of Ibadan, Ibadan and Obafemi Awolowo University, Ile-Ife. One of the factors that contributed to this patronage is security - an assurance of well-being of both the performers and audience in all ramification. By the beginning of 1990s, there was an evident paucity of stage play productions, and patrons had reduced in the few remaining theatres that strived to put up shows. Using the explicit knowledge of performance environment of the country as a participant observer and an active member of the industry for close to three decades; the paper establishes that the moribund state of live performances in Nigeria is closely connected to the gamut of insecurity that has invariably left theatre business in the shadows of itself. Hence, this paper is a review of security issues in the nation as it affects theatre business, particularly live performances, and the resultant hardship on getting the desired therapeutical, psychological and entertainment values embedded in its forms. The paper investigates the low turnout of audience at live theatre in Nigeria and establishes the reasons why it does not seem to hold any adequate moneymaking potential to encourage investors. The paper concludes with the hope that if the Nigerian government could be responsible for managing and sustaining the art, there would be a great succor and healthy environment for live theatre to thrive.

Keywords: Security, dearth of live performance, theatre patrons, live theatre, Nigerian theatre.

\section{Introduction}

Historically, theatrical performances as seen from the time immemorial have always been a communal effort collectively enjoyed by people of various households, and there have been spaces for performances which were considerably safe for the audience to watch. In the traditional Nigerian society, result of good security was evident in the overnight display of fruits and vegetables on the Nigerian highways without anybody keeping watch and yet, the fear of stealing was nonexistence. In fact, the owners always met their wares as left. Such was the peace and tranquility people breathed in the air of Nigerian society then. It was with this peaceful atmosphere that moonlight storytelling thrived at the frontage of houses built with little or no fence.

In the traditional or indigenous Nigerian setting, performances were done without fear or trepidation at performance venues. But, with technological development came the fear of the known and the unknown; 'I know it is not safe outside', 'I better leave the hall before the curtain call to avoid molestation by hoodlums'; 'Who is the next person seated by me?', 'Is my car safe at the car park?', 'Is this performance going to end well or with a bomb blast, (courtesy of 'Boko Haram')?'. All these and many more are the risk taken to attend a production in a Nigerian theatre today, though there is an appreciable improvement in the attendance of cinema audience in the country since most of the newly produced films are seen at cinemas, either as premieres or for regular shows. The Ben Bruce-owned Silverbird Cinemas is a leading example of such screening centres that assist the Nigerian film producers to make quick money before their works are pirated.

However, this paper is focused on live theatre performances at established theatre venues such as the National Theatre of Nigeria, Iganmu , Terra Kulture, Glover Memorial Hall, the Muson Center, the German-owned Goethe Institute and the French Cultural Centre. All of these theatres are based in Lagos because, first and foremost, the city is the hub of entertainment in Nigeria and predominantly highly populated, hence, it will be a good case to study. Secondly, theatregoing is not a commonplace culture in other towns and cities in Nigeria except for University campuses where there are still evidences of passion for live theatre, and this is so because most of the campuses enjoy considerable security within their environment aside the freedom of night lives for academic works and socialization. 


\section{The Beginning of Live Theatre in Nigeria}

The beginning of live theatre in Nigeria can be traced to the popular Yoruba Travelling Theatre movement of the 1940s to 1980s. Adedeji recorded that this movement emanated from the dramatic roots of Egungun performance in Yoruba ancestral worship and as a court entertainment during the reign of Alaafin Ogbolu of Oyo Kingdom in 1590, under the leadership of Ologbin Ologbojo. With the expansion of Oyo Empire, the court was extended to provinces which ultimately caused an increase in the number of troupes to aid the operational system. However, court life was disrupted by the first half of the nineteenth century due to slave trade and internecine wars, and this adversely affected the theatre as presented in the palace. With no court administration in place, several troupes sprang up beyond the Ologbojo lineage and they were free to entertain individuals or group of people who invited them (Ogunbiyi, 1981, p. 226). Before long, the troupes started moving out of the egungun cult, tending towards professionalism when Esa Ogbin, a maternal relation of Ologbin Ologbojo, took the theatre to the masses (p. 224), and that was when the masque-dramaturge became known as "Alarinjo", (itinerant dance troupe).

The advent of colonialism brought about the influence of foreign religions and subsequently, Christianity marked down theatrical performances as fetish and ritualistic. Later on in the churches, and in furtherance of making gospel truth clear to everyone, the same religion used dramatic presentation to advance the tenets of the Bible. Such performances were done at annual church festivals like Easter and Christmas, anniversary ceremonies of churches as well as such adventitious circumstances that called for fund-raising (Adedeji \& Ekwuazi, 1998, p. 46). It was during this period that Hubert Ogunde, whose theatrical footings was had during the dying phase of Alarinjo as a young person; and who grew under the influence of masqueraders, infused movement and action into cantatas as a Music Director in the Church of the Lord.

Ogunde later started his own full-fledge troupe in 1945, and by the following year, his travelling theatre troupe became highly popular and successful within and outside Nigeria. The vitality of the travelling theatre movement, coupled with Ogunde's efforts 'steamrolled Nigerian theatrical developments into the orbit of professionalism' (ibid. p. 81). A culture of theatre-going was nurtured and established to the delight of all and sundry that Wole Soyinka in his opening remarks at the forum organized by the University of Ibadan, to celebrate 25 years of the Yoruba Operatic Theatre Movement said: 'it is a celebration of what has become a dramatic feature of life in Nigeria and on the coast of West Africa' (ibid.). But regrettably, this exceptional feat has gone moribund in this era of technology. Many factors attributed to the decline of what used to pull people from all strata of the society together in theatres, town halls, school halls and in palaces such as, poverty, ill-funding, television, home video films and safety of lives and properties.

These problems are all swathed in security as an issue. But before we discuss them in details, it is germane to look at the reason(s) why live performance is special and exceptional that it cannot be compared with other forms of presentation in spite of its transitory presence.

\section{Features of Live Theatre}

It is hard to find any commentary on live performance that does not subscribe to the power of the phenomenological lived experience of the event, as opposed to its "representational" or symbolic intentions.

Melissa Trimingham (2011, p. 66)

Live theatre is any theatrical performance presented on a stage to a seating audience, or a performance watched by a paying audience. There is therefore measurable difference in the pleasure and excitement derived in watching a live performance compared to screening of a movie, either in a cinema hall or as a home video film. It thrills the audience to see the drama unfold around them and it creates a sense of belonging or sharing with the actors on stage. Borev (1981, pp. 256-257) believes that an important feature of the theatre is that the creative act (the creation of the image by the actor) takes place before the eyes of the spectators and that gives the theatre tremendous influence on the minds of the audience. In the cinema, the spectator sees the result of the creative process while in the theatre he sees the process itself. This goes a long way to explain the fascination of the theatre. There is 'dynamics of blending that involves attention, memory, empathy and heightened emotions' (McConachie, 2008, p.19).

Peter Brook, the renowned English theatre and film director, equally stated that performance brings together two worlds of the stage and auditorium in an exquisite union as it produces an experience of vital immediacy between the performers and the audience. He sees theatre as a live performance of 'here and now', while Montassier (1980), who defines live theatre as 'what happens at that precise moment when you perform, that moment at which the world of the actors and the world of the audience meet' (p. 122), champions the existential moment that is forged between audience 
and performer. He maintains that the audience co-creates the play with the actors by an active participation in the event through the suspension of belief, and this makes it a 'communal experience' that is heightened by the fact that both audience and players are physically in the same space (Shores, 2008, p. 20).

Shughnessy (2012) also posits that such performances are ever present and they require us to be in the here (space of performance) and now (time) (p. 39). The essence and beauty of the 'now' is what enthralls in watching a performance live. It sooths and moves the inner being towards the actions on stage. Spectators experience the materiality of a live performance as an ephemeral event, rather than interpreting it as a static or mediated work of art created by autonomous artists. There is therefore, the ability of the performance to generate heightened energy by sight, sounds, smells, and spatial arrangement as they are encountered (Fischer-Lichte, 2008, p. 495). This experience presents an audience-performers and performers-audience relationship unlike the orchestrated acting and reaction gotten in other forms of theatrical media.

Apart from the entertaining function of a theatrical performance; live theatre can serve as a psychological therapy. Barclays Ayakoroma, while delineating live theatre from cinema tradition in his keynote address at the annual celebrated International Theatre Day (ITD 2012), at Abuja, says:

Live theatre is characterised by psychological immediacy - the living presence of the actors and the audience in a performance environment. This is one major advantage the theatre has over the screen - TV/Film. The actors and the audience have the capacity of influencing the other, positively or negatively- a good response from an audience spurs the actors on stage, just as negative reactions may demoralize the actors and hinder the production.

Whether a show is presented in a day or runs for nights; live theatre is transient in nature, which makes the psychological immediacy enchanting. Once presented, the nostalgic effects it has on the audience and the eagerness to continue seeing the shows always stands the text of time. Also, the atmosphere in a live theatre scenario is mostly serene or bustling; depending on the mood of the production that calls for total concentration. All these special and unparalleled qualities cannot be compared with the blithe that is allowed in the continuous rewinding of a compact disc (CD) or a cassette for home viewing. The 'live' experience stands fresh as ever and as many times as the performance is re-presented. There is an intangible ephemerality to it that makes the ecstatic and sometimes interjectory experience similar to the taste found in eating pudding. These unrivalled elements that are therapeutic and educative in their spontaneity make it rather preposterous to be scarce in the present day Nigerian society, and that is where the issue of security comes in the picture.

\section{Theatre and Security}

Security is a general term for a condition of protection against or safety from bad occurrences and it can apply to human lives, assets and other vulnerable things. For the purpose of this paper, security will be looked at as it relates to investment in productions, making a livelihood out of productions, protection of lives and properties, and the effect of technology. The paper will attempt an overview of security in these different forms as it relates to the theatre and how they have contributed to the near non-existence of live theatre in Nigeria.

\subsection{Investment Insecurity}

Sponsorship or investment in the arts is the first type of security that is currently dealing a great blow on the essence of theatrical productions in Nigeria. Theatre is supposed to be subsistent on some form of assistance from the government as obtained in most advanced countries, but the Nigerian government is not ready to shoulder any responsibility for the arts and there are no investors that are readily found except for few not-too-common organizations like Computer Hardware and Maintenance Services (CHAMS) PLC that invested in the productions of D.O. Fagunwa's works for two years between 2008 and 2009 in drama series.

Many of the multinationals, private sectors and individuals that can comfortably support the theatre have shown an indifferent attitude towards sponsorship of live theatre. They either feel it cannot get the mileage they expect or that recouping their monies back could be difficult, hence, huge sum of their capital is thrown into reality, quiz, and gambling shows like Guilder Ultimate Search, Who wants to be a Millionaire, and Lotto Baba ljebu respectively. While these shows provide quick returns financially and wide audience coverage, investment in the art of the theatre is a product of passion and might not bring much financial gains. A theatre investor must be someone that has the zeal and willingness to promote the art in spite of financial gains which makes the ultimate goal to be the fulfillment found in the presentation. 
This does not mean that live theatre cannot also be profitable. But in case it does not, there should be gratification of contentment gotten as an art lover, patron and promoter. There is therefore, dearth of investors because of nonassurance of recouping of seed money put into performances.

\subsection{Artistes Remuneration}

Sequel to the problem of investors is a low and ridiculous artistes' fee paid the cast and crew in productions. Mostly, the rate of artistes' fees for stage productions in Nigeria is appalling compared to what is paid to screen actors. In a standard outfit, live theatre is expected to be on for six weeks of intensive rehearsals before performance, (though some people use fewer periods to perfect their acts) and at the end of the rehearsals; what many of the actors are paid is outrageously low. With no sponsors or assistance from any organization, there is bound to be little to share after the box-office returns are checked. Few performances that have been able to feed stage actors are the command performances paid for or subsidized by an organization. Of recent, some states government started the fashion of incorporating live performances into their administration anniversary celebrations, and of course, that comes up once a year. Lagos, Nassarawa, Oyo, and Osun states had taken turns to do this in the last few years, the latest being Wale Ogunyemi's Langbodo, commissioned by the Ondo State Government in 2012. Participating in such 'once-in- a- year' command performance will definitely not suffice to put food on the table for any adult in any given society.

\subsection{The Effects of Technology}

The third type that is the thorn in the flesh of live theatre is technological advancement, which has shifted the focus away to the screen. There are many advantages for the theatre in a technological advanced space, and at the same time, it has its negativity that has deeply affect the root of performance. When the Nigerian radio and television stations extended hands of recording fellowship to the Yoruba Travelling Theatre troupes in the early seventies, it was in their minds that that would advance the audience base and not cut it down. Ogunleye (2007) describes the enthusiasm of members of the troupes when 'the recording of such plays helped to improve the art of the troupes, and also increased the number of people who watched their plays' (p. 12). For a long period of time, the first television in Africa, the Western Nigerian Government Broadcasting Corporation (WNTV), recorded and broadcasted different live performances of the Yoruba travelling theatre troupes and they were still touring at the same time. Somehow, this was the stylish beginning of the end for live theatre in Nigeria which was sadly followed by the economic recession of 1980 s.

The strict and 'structural adjustment' of the Nigerian economy had adverse effects on the economy of the travelling theatre troupes that were feeding the populace with productions in performance spaces. It was the same period that focus was shifted to the production of $35 \mathrm{~mm}$ films by the rich troupes like Hubert Ogunde's, Adeyemi Afolayan's and Moses Adejumo's who produced with the help of Ola Balogun and some foreign film makers. Later on, the advent of a much cheaper style of recording, home video film, became convenient and handy for most theatre practitioner to venture in. This means that the theatre has been taken not only to the doors of the audience, but, to their sitting rooms. Soap Operas also became an added salt to the home video injury for live theatre productions. People are left with many options to pick from - soaps, series, and home videos.

International playwright and scholar, Tess Onwueme also expresses her opinion about home video screening been the clog in the wheel of live theatre progress, stating that it started with 'the democratization of channels of entertainment, and viewership which means that people are less animated about going to the theatre.' she affirms that the National Theatre of Nigeria still had a vibrant theatre culture in the 1980s, but the introduction of the mass media; especially the soap operas and home video films, has changed the outlook of its patronage. Everyday, television stations now run home video films in full, i.e. from the beginning to the end, which makes a lot of people feel there is no reason going to a 'National Theatre' to watch live performance. If one misses watching one film at a given station; there would always be another in a sister station. This entire arrangement has aided the reduction in theatre goings. Below is a typical viewing chat for home video films on Nigerian television stations:

$\begin{array}{lll}\text { Television Station } & & \text { Slots } \\ \text { Silverbird Television (STV) } & - & \text { 8a.m daily } \\ \text { Ogun State Television (GTV) } & - & \text { 7a.m daily } \\ \text { Galaxy Television } & - & \text { 9a.m.daily } \\ \text { Television Continental (TVC) } & - & \text { 9a.m daily } \\ \text { OnTV Nigeria } & - & \text { 9a.m daily }\end{array}$

If the above listed stations with the exclusion of cable TV such as DSTV, Hitv, and CMTV, could be showing films 
produced both in English and Yoruba languages as shown above, then the rate of audience at theatres will definitely reduce.

\section{Security of Lives and Properties}

Theatre has always been peoples' show and place at the same time. Theatre, when seen as a performance, is an audience-based act; and theatre, as a building where theatrical performances are shown is also audience -based. Whichever way it is looked at or addressed; theatre in an act of the artistes - singers, actors, dancers, drummers and so on - and the audience. There must be someone watching a show, and the well-being of such person(s) is the duty of the performers or the manager. Langley (1980), while highlighting the list of facilities related to the audience area in a standard theatre structure, insists the inclusion of security as vital as the performance itself and its non-availability could devalue the building and can add to the failure or success of artistic objectives (56). Hence, security is highly crucial to an idea of a performance; be it in a regular venue as found in theatre structures, or arranged venues like a village square or market place. The audience must have a sense of safety to be able to concentrate on the performance.

Nevertheless, there are some ardent theatre practitioners and association that never stopped presenting plays despite the low turnout or sponsorship: Jude Partrick-Jude Oteh of Jos Repertory Theatre, Segun Adefila's Crown Troupe of Africa, Yemi Akintokun's Oracle Theatre, and the National Association of Nigerian Theatre Practitioners' annual Festival of Nigerian Plays (FESTINA). These people and association have continued with shows to maintain the legacy that gave birth to other forms of presentation, and sometimes had to cope with the state of security in performance venues. If theatre had to be presented to a wide range of audience, then there is the need to beef up security in and around the venues. The few patrons they have are often threatened by molestations from area boys and of recent, the religious fundamentalists' bomb threats.

There are quite a number of venues where these scanty live performances still take place, most especially in Lagos; government and private-owned theatres such as the National Theatre, Planet One, Terra Kulture and Muson Centre. Most of these venues except the National Theatre (established to be the primary center for the performing arts in Nigeria, though built as a venue for the Festival of Arts and Culture (FESTAC) in 1977), are situated in the highbrow area of the city; Victoria Island, which suggests a high rate of gate-takings and invariably they become the exclusive preserve for very few people, especially the rich. The kind of security put in place in these privately-owned venues makes the audience a bit comfortable to watch shows there, unlike the public structure put in place for the generality of Nigerians once known as a cultural edifice and the nation's pride, the National Theatre.

Ideally in theatres, the operators or Managers are to be responsible for the security of lives and properties of the audience and there is the need for more detailed scrutiny of performance environment as Conte and Langley (2007, pp. $57-58,419)$ suggested. There should even be an increase in the concern for security in public places and it is also necessary to pay special attention to security measures and procedures and seek advice from local authorities and security experts.

From the situation of events, the Nigerian government itself is visibly struggling with the incessant attempts on lives and properties of her people, and is trying to stem the various types of insecurity in all quarters within the nation. In 2011, there was a security alert during the Christmas season that people should steer clear of public places to avoid being bombed by Boko Haram terrorist. This has led to security checks everywhere; shopping malls, University campuses, banks, and even churchgoers are now put under scrutiny before entering the worship building.

\section{The Way Forward}

With the mass appeal and acceptance enjoyed by live theatre in Nigeria between 1940s and 1980s, one would have expected the endowment of the arts suggested in the Nigerian Cultural Policy be put in place to support the culture sector, but decades after its publication, nothing has been done to assist the art which has been left to thrive on its own. The Nigerian government should rid itself of its noncommittal to the art and culture sector to lead the race for theatre survival by its subventions, and strengthening security of lives and properties, which will ultimately flow down through and to all sectors of living. If lives and the environment are secured, it will definitely bolt the other forms of security disturbing the viability of live theatre performances all over the country; investors will be willing to try the waters of live performances which will encourage the artistes' psyche and willingness to work, and it will ultimately culminate into having good turn out of audience at shows again.

Also, having just one or two theatres where stage performances are regularly presented will not suffice to revive live theatre in Nigeria as against the numerous venues available in the 1970s to 1980s (Ogunbiyi, 1981, p. 237; Jeyifo, 
1984, pp. $17 \& 65)$, whereby most towns have viable theatre houses and shows were going on periodically. There is therefore the need to further make available venues that will consistently churn out live theatre in secured environment high quality theatres - where both the lower and upper classes can get the worth of their money.

\section{References}

Adedeji, J.A., \& Ekwuazi, H. (Eds.). (1998). Nigerian Theatre: Dynamics of a Movement, Ibadan: Caltop Publications.

Ayakoroma, B. (2012). To Be Or Not To Be.. Keynote Paper delivered at the National Association of Nigerian Theatre Arts Practitioners' (NANTAP) organized International Theatre Day celebrations, March 27, 2012. Abuja.

Conte, D., \& Langley, S. (2007). Theatre Management: Producing and Managing the Performing Arts, USA: EntertainmentPro.

Fisher-Lichte, E. (2008). The Transformative Power of Performance: A New Aesthetics. New York: Routledge.

Langley, S. (1980). Theatre Management in America: Principle and Practice. New York: Drama Book Publishers.

Malomo, J. (2002). The Theatre Audience in Nigeria. Ibadan: Stirling-Horden.

McConachie, B. (2011). Engaging Audiences: A Cognitive Approach to Spectating in Theatre. Basingstoke and New York: Palgrave.

Montassier, G. (1980). Le Fait Culturel, Paris: Fayard. p. 122

Ogunleye, F. (2007). Theatre in Nigeria: Different Faces, Ibadan: Humanities Publishers

Onwueme, T. (2012, October 20). Versatility, Multi-media Consciousness are Ingredients of Enduring Theatre Practice. The Guardian. Retrieved October 21, 2012 from www.ngrguardiannews.com

Shores, J. (2008). Christian Theatre and Entertainment-Education: Belief System Theory and the Impact of Live Performance. Michigan: ProQuest.

Shaughnessy, N. (2012). Applying Performance: Live Art, Socially Engaged Theatre and Affective Practice. UK: Palgrave Macmillan.

Trimingham, M. (2011). The Theatre of Bauhaus. London and New York: Routledge. 